\title{
W cieniu deszczowego drzewa. Antropologiczne zapiski z Fortu Kochi
}

\author{
Katarzyna Najmrocka \\ Akademia Humanistyczno-Ekonomiczna w Łodzi \\ ul. Sterlinga 26, 90-212 Łódź \\ k.najmrocka@gmail.com・0RCID 0000-0002-3546-2489
}

\section{Streszczenie}

Dziedzictwo zieleni keralskiego miasta Fort Kochi obejmuje olbrzymie drzewa, które wedle legendy pamiętają koIonialną przeszłość. Są więc żywymi pomnikami pamięci, wokół których ogniskują się konteksty społeczno-kulturowe. Mieszkańcy Fortu identyfikują się z owymi olbrzymami, upatrując w nich strukturę długiego trwania. Wielkie figowce i deszczowa drzewa utożsamiane są z drzewem-matką - swoistym życiodajnym źródłem energii wszystkich mniejszych drzew - połączonych ze sobą podziemnymi systemami korzeniowymi. Odnajduję w tym analogię do miejskiego krajobrazu Fortu Kochi, który tworzy ów starodrzew. To osobliwa siatka powiązań: historycznej identyfikacji, kulturowej tożsamości oraz emocjonalnej mapy ludzkich życiorysów, które toczą się w ich cieniu. Mieszkańcy upamiętniają stare olbrzymy dekoracjami festiwalowymi, czyniąc z nich symbol wielokulturowej społeczności miejskiej, która żyje w symbiozie z naturą.

\section{Słowa kluczowe}

Indie, Fort Kochi, dziedzictwo zieleni, miejsca pamięci, drzewo deszczowe

Pod koniec września w samo południe zabłądziłam w indyjskim mieście Kochi - ściślej mówiąc - w jego starej części nazywanej Fortem $^{1}$. Dokuczył mi żar lejący się z nieba i pragnienie, które powoli zsyłało ból głowy. Udało się zlokalizować zacieniony zaułek z małym sklepikiem przy ulicy. Sprzedawano tam rzeczy pierwszej potrzeby, czyli ciepłe samosy, owoce, zimne napoje i asortyment charakterystyczny dla polskich kiosków ruchu. Po ugaszeniu pragnienia, przeszłam na drugą stronę ulicy, by móc wesprzeć się o rosnące tam drzewo i wytchnąć w jego cieniu.

1 Fort Kochi również określany jest jako Fort Koczin, Fort Cochi. Pozostaję przy pisowni Kochi.
Cóż to było za drzewo! Olbrzymi pofalowany pień z gigantyczną koroną, która roztaczała się nade mną, nad ulicą, przeciwległym chodnikiem i sklepem wraz z pobliskimi budynkami. Drzewo zacieniało tak dużą powierzchnię, iż zapomniałam na moment o upale. Dłuższą chwilę mogłam obserwować życie toczące się w tym chłodnym azylu. Splątane gałęzie w koronie, zwisające drobne liście przypominające akację, które wyrastały zarówno z konarów, jak i niektórych partii olbrzymiego pnia, tworzyły niezwykły baldachim, który nie przepuszczał promieni słonecznych. Pod drzewem znajdował się przystanek autobusowy - dzieci w szkolnych mundurkach wyczekiwały na pojazd, 
a ubrane w kolorowe sari kobiety prowadziły rozmowy. U jego pnia spał zwinięty w kłębek niewielki pies charakterystyczny dla południa Indii. Przy lokalu zgromadziło się kilku mężczyzn, którzy wypili z dużej butelki po kieliszku mętnego płynu. Butelka nie stała na widoku, ale nie była też specjalnie ukryta, co - jak na Keralę objętą prohibicją - nie było wcale oczywiste. Kultura zawsze znajduje boczne furtki dla zakazów, przez jedną z nich przepływa wino palmowe - trunek trudny do przełknięcia przez niezaprawione gardło. Mężczyźni pożartowali głośno, pożegnali sprzedawcę i rozeszli się w swoje strony. Jakie sekrety skrywa owo drzewo, jakie zna historie, jakich scen było świadkiem - pomyślałam. Przyjemnie upływały minuty z dala od upału, jakże cudowna była ta majestatyczna roślina, która w sposób nienachalny zaaranżowała przestrzeń tak przyjazną wszelkim stworzeniom szukającym schronienia przed południowym słońcem tropiku.

Kerala to stan w południowo-zachodnich Indiach, którego konteksty kulturowe, religijne, ekonomiczne i społeczne są nierozerwalnie związane z florą i fauną. Tutaj rozpościera się pas morskiego wybrzeża porośnięty gajami kokosowymi, z których wyrabia się olej, kosmetyki, sznurki i materace. Rosną tu również drzewa sandałowe znane na całym świecie w przemyśle perfumiarskim i kosmetycznym. To one tworzą niepowtarzalny olfaktoryczny klimat Indii - jako nieodzowny składnik olejków, perfum i kadzideł. Wśród królestwa drzew rozpoznaję papaje i mangowce, które chętnie są sadzone w ogrodach przydomowych. Rosną też zdumiewające czerpnie gujańskie, zwane kulami armatnimi (Cannonball) na cześć wielkich owoców i pokaźnych kwiatów, które wyrastają wprost z pnia (Web-o1). Nazwa może referować do uszkodzeń głowy, których doznaje się w wyniku spotkania ze spadającą owocową kulą ${ }^{2}$. Czerpnie za dnia wabią nektarem pszczoły, a o zmierzchu nietoperze -

2 Podobne zagrożenie stwarzają kokosy. W celu uniknięcia wypadków zakłada się specjalne siatki, stosuje znaki ostrzegawcze, bądź też zatrudnia ludzi, którzy zajmują się ścinaniem orzechów. rudawki wielkie. Niektórzy uważają, że pod czerpnią urodził się Budda Siddharta. Hinduiści natomiast czczą drzewo przez wzgląd na afiliację z Shivą. Tutaj rośnie też cała grupa drzew $\mathrm{z}$ rodziny bobowatych - o drobnych akacjowych liściach i kolorowych kwiatach, które po przekwitnięciu zamieniają się w długie strąki podobne do fasoli. Królują tu drzewa asioka (Ashoka) i strączyniec cewiasty (Golden Shower). Ten ostatni jest symbolem Kerali - zaraz obok palm kokosowych i majestatycznych słoni. Do kolosów drzewnych można zaliczyć również baniana, czyli figowca - święte drzewo - pod jednym z nich doznał oświecenia wspomniany już Budda. Banian służył również jako baldachim zacieniający uliczne sklepiki, dał więc nazwę kaście kupców - Bania, którzy często w cieniu rozłożystych drzew banian rozstawiali swoje stragany i organizowali sklepiki (Web-o2, Web-03). Nie sposób oddać honoru wszystkim drzewom, z antropologicznego jednak puntu widzenia niektóre $\mathrm{z}$ nich układają się w ciekawą konfigurację kulturową. Dotyczy ona przeszłości postkolonialnej i stanowi naturalne dziedzictwo kulturowe regionu. Są to drzewa, które dekoruje się na święta, darzy szczególnymi uczuciami i wspomina w ich cieniu wielkiego podróżnika - Vasco da Gammę. Społeczność rewiduje tym samym swe wielokulturowe korzenie - nawiązuje do przyszłości, której Keralczycy nie wyobrażają sobie bez drzew deszczowych - kolosów, będących tu niemalże metaforą kamieni węgielnych.

Jedno z nich dało mi schronienie przed upałem. Nazywane jest potocznie deszczowym (Rain Tree ${ }^{3}$ ) oraz drzewem-matką

3 Niektóre źródła podają, iż drzewo deszczowe jest figowcem pagodowym, z tej samej rodziny co banian, inne przypisują mu afiliację gatunkową $\mathrm{z}$ ablicją samam - pochodzącą $\mathrm{z}$ rodziny bobowatych. Oba drzewa są długowieczne i osiągają wielkie rozmiary. Drzewo, które służyło mi jako zacieniony azyl, było spokrewnione z ablicją (liście charakterystyczne dla bobowatych), natomiast kolos nieopodal kościoła wskazuje na rodzinę figowców (charakterystyczny pień składający się jakby ze zrośniętych mniejszych drzew). Określenie drzewo deszczowe 
(Mother Tree), a w keralskim języku malayalam - Ammachi Aalu. (Web-o4, Web05). Nie ma przesady w personifikacji Ammachi z matką. To jedne z najstarszych pomników przyrody w tym regionie. Drzewom deszczowym przypisuje się również długowieczność. Suzanne Simard, ekolożka leśna, uważa, iż mianem drzewa-matki określa się najstarsze i największe z drzew, które łączą się życiodajną energią $\mathrm{z}$ innymi gatunkami za pośrednictwem mikoryzy - transportu związków pokarmowych za pomocą grzybów. Istnieje przekonanie, że w przypadku gdy takie drzewo obumrze, zdąży wcześniej przekazać życiodajne substancje pozostałym pokoleniom roślin, zapewniając swoistą ciągłość ekosystemu (Web-06).

Najstarszy egzemplarz z Fortu Kochi, znajdujący się w sąsiedztwie kościoła pw. św. Franciszka, jest przedmiotem romantycznych domysłów i dyskusji. Na łamach dziennika "The Hindu” drzewo zyskało miano świadka pokoleń: „Zakorzenione we własnej sile, $\mathrm{z}$ rozległym cienistym baldachimem drzewo symbolizuje nieskończoność, majestatyczność i powagę. Dla różnych ludzi przyjmuje odmienne znaczenia. Dla jednych jest dumą Fortu Kochi, innym udziela cennej lekcji dotyczącej wytrwałości i siły, a dla pozostałych reprezentuje odwieczny cykl życia” (Web-o7).

Niektórzy sądzą, iż ma 200 lat, a inni przypisują mu nawet wiek 500 lat (Web-o7). Wskazuje ono na pamięć zamierzchłych czasów portugalskiej kolonii, budowania pierwszego chrześcijańskiego kościoła w Indiach i postać Vasco da Gammy. Portugalski odkrywca jako pierwszy wytyczył drogę morską do Indii, przywiózł nad Wybrzeże Malabarskie zarówno europejskie idee chrześcijaństwa, jak i otworzył świat na handel z Azją Południową. Uczynił też portowe miasto Kochi ówczesnym centrum handlowym, przez które przepływały nie tylko towary, lecz także kultury i idee. Finalnie nie gdzie indziej, jak w Kochi, zakończył swoją doczesną podróż. Kościół pod wezwaniem

(Rain Tree) jest zatem przypisywane największym okazom drzew z Fortu Kochi. świętego Franciszka do dziś szczyci się grobem, w którym spoczywały niegdyś szczątki wielkiego podróżnika (zanim przewieziono je do Lizbony).

Słynne deszczowe drzewo, sąsiadujące z kościołem, było więc świadkiem powolnych zmian kulturowo-społecznych, które kształtowały się na przecięciu religii i kultur: hinduskiej, muzułmańskiej, chrześcijańskiej, judaistycznej i protestanckiej. Ten styk kultur, budowany przez stulecia bezkonfliktowej koegzystencji różnych nacji, religii i kast, przyczynił się do zachowania zarówno tradycyjnej kultury ${ }^{4}$, sztuki i architektury, jak i dziedzictwa naturalnego zwanego tu dziedzictwem zieleni (greenery heritage) - jakże ważnego z punktu widzenia mieszkańców całego stanu Kerala. Nie ma już znaczenia, czy rozstrzygnięcia wieku drzewa przypadną na 500 czy 200 lat (Web-o8, Web-o7). Romantyczna wizja przeszłości i duma z wielokulturowego dziedzictwa czyni je swoistym symbolem - strukturą długiego trwania. Jeden $\mathrm{z}$ osiemdziesięcioletnich mieszkańców wyznaje: „Drzewo było odkąd każdy sięga pamięcią. Podczas tamtych dni zapewniało schronienie i cień widzom licznych meczów krykieta na Placu Parade Ground. Utrzymuje się, że zostało zasadzone między 150 a 200 lat temu przez Europejczyka - przewodniczącego Magistratu Fort Cochin, który był wielbicielem drzew. Przypuszczalnie to on zasadził wszystkie drzewa wokół placu. Plac Apelowy Parade Ground przyjął swoją nazwę w związku z brytyjskimi wojskami, które tam defilowały. Istnieje zatem powód, by twierdzić, iż drzewa zasadził Europejczyk" (Web-07).

Deszczowe drzewa, wielkie kolosy pamiętające czasy portugalskich handlarzy, bądź

4 Krzysztof Renik, diagnozujący keralskie dziedzictwo tradycyjnych form teatralnych, upatruje ciągłość i chęć do zachowania owej tradycyjnej sztuki właśnie w wielokulturowej harmonii regionu (Renik 1996).

Warto również za historykiem Janem Kieniewiczem dodać, iż historia podbojów Kerali nie miała aż tak dramatycznego przebiegu, jak inne regiony Indii (Kieniewicz 1980). 
też symbolicznie świadczące o wielokulturowym dziedzictwie historycznego portu w Kochi, wpisały się w krajobraz miejsc pamięci - lieux de mémoire - opisywanych przez Pierre'a Norę. Francuski badacz konsekwentnie unikał dokładnego zdefiniowania owych. Zaznaczał jednak, iż są to zinstytucjonalizowane formy zbiorowych wspomnień z przeszłości, co było dość pojemne znaczeniowo. Oznaczało zarówna archiwa historyczne, jak i pomniki bohaterów. Warunkiem było, aby dana społeczność w owym miejscu składała swe wspomnienia jako nieodłączną część swej osobowości (Szpociński 20o8: 3). Chodziło wszak o obecność przeszłości w teraźniejszości. W swoich pracach Nora podkreślił również istotną rolę aktywności, które zmierzały do zachowania i podtrzymywania pamięci o przeszłości. Andrzej Szpociński wyjaśnia: „Miejsca pamięci funkcjonować mogą tylko w takich kulturach, w których respektowane są przekonania o tym, że pewne przedmioty (posłużmy się tu trawestacją sformułowania Paula Ricouera) «mają nam coś do powiedzenia» o przeszłości. To samo można ująć jeszcze inaczej: nabieranie przez pewne przedmioty statusu «miejsc pamięci» sprawia, że w obszarze danej kultury zaczyna funkcjonować reguła orzekająca o tym, iż przeszłość dana jest nam nie tylko w relacjach bezpośrednich świadków zdarzeń, lecz także pośrednio - poprzez znaki i symbole" (Szpociński 2008: 11).

Zatem miejsca pamięci ${ }^{5}$ można rozumieć metaforycznie (znaki, symbole) i realnie (pomniki, świątynie, muzea). Z punktu widze-

5 „Chcąc uniknąć sytuacji tworzenia terminów ponad potrzebę, proponowałem, by o «miejscach pamięci» mówić jedynie wówczas, gdy: po pierwsze, pewne zdarzenia, osoby, wytwory kulturowe postrzegane są w potocznej świadomości jako własność określonych grup lub zbiorowości, a po drugie, gdy postrzegane są one jako depozyt (symbol) nie tylko jednej konkretnej wartości, lecz rzeczy ważnych w ogóle, ważnych dla wspólnoty, jako rodzaj «miejsca», w którym znajdują się i mogą być odnajdywane coraz to inne cenne wartości" (Szpociński 2008: 15). nia zbiorowości są one jednak niezwykle ważne, bo wyrażają wartości, normy i idee. Niebagatelne znaczenie ma tu przekaz pokoleniowy, który służy niejako rozpamiętywaniu przeszłości. Rzecz analogicznie ma się w przypadku kolosów z Fortu Kochi, wokół których powstały legendy - ciągle żywe w opowieściach mieszkańców.

Jeśli można zakładać, że struktury długiego trwania, tak mocno związane z postrzeganiem czasu linearnego, są $\mathrm{w}$ pewnym sensie przeżytkiem kultury współczesnej (zwracał na to uwagę Z. Bauman), miejsca pamięci - nierozerwalnie związane z pamięcią, ciągłością i przeszłością zbiorową - nabierają dziś wymiarów wizualizacji i teatralizacji. Tak twierdzi Szpociński (Szpociński 20o8: 16). Chodzi tu o happeningi i działania performatywne, przedsięwzięcia nastawione na bodźce wizualne, oparte często na technikach audiowizualnych. To czyni owe działania atrakcyjnymi z punktu widzenia młodego pokolenia, spadkobierców pamięci.

Nie inaczej jest w Forcie Kochi. Podczas Świąt Bożego Narodzenia wielkie drzewo deszczowe dekoruje się lampkami oraz wszystkie pozostałe kolosy wraz z sąsiadującymi domostwami (nie wykluczając tradycyjnych chińskich sieci na nabrzeżu portu). Potrzeba celebrowania święta chrześcijańskiego w tym wielowyznaniowym mieście to jedno. Drugi aspekt - zdecydowanie bardziej uniwersalny - nawiązuje do ludycznego charakteru przełomu roku. Chodzi o idee jedności mieszkańców Fortu - wpisaną w tutejszą zasadę wspólnej koegzystencji. Dodatkowo jest to czas nie tylko świąt chrześcijańskich, lecz także karnawału, który przyciąga wielu turystów. Zaczyna się on w połowie grudnia i jest obchodzony bardzo hucznie. Władze dokładają wielu starań, by karnawał - zwany festiwalem - przyciągnął atrakcyjną oprawą jak najwięcej ludzi, w tym turystów. Festiwal zatem ma urozmaicony program - od zawodów na plaży i barwnych pochodów ulicznych, po pokazy tradycyjnych tańców i sztuki Kathakali. Pod drzewem odbywa się więc karnawałowa zabawa 
w rytmie muzyki tanecznej. Fort Kochi dodatkowo wchodzi wówczas w szczytowy moment sezonu turystycznego, którego ambicją jest konkurowanie z popularnym Goa. Drzewo zamienia się w dyskotekową kulę, która nadaje azymut wieczornej rozrywce. To właśnie w nocy, gdy nie doskwiera upał, można oglądać uroczyście oświetlone centrum Fortu i tłumy ludzi szukających zabawy, podziwiających odświętnie zmienioną okolicę lub po prostu celebrujących nadciągający nowy rok (Web-o8).

O ile kolonialna przeszłość Indii może wzbudzać dyskusje, „podbój” Wybrzeża Malabarskiego przez Portugalczyków był stosunkowo bezkrwawy, oparty w dużej mierze na handlu (przynajmniej tak sądzili witający ich w owym czasie Indusi). Fort Kochi z perspektywy czasu jest postrzegany jako pozytywny przykład polityki kolonialnej. Jest to jednak znacznie uproszczona konkluzja, szczególnie kojąca sumienie Europejczyków. Niektórzy badacze uważają wszak, że w tle każdej przeszłości kolonialnej (nawet tej bezkrwawej i pokojowej) pobrzmiewają znamiona przemocy - chociażby symbolicznej. Socjolog Tony Bennett zwraca uwagę, iż do dziś wśród zabytków Fortu są te, które wskazują na ciemną kartę z czasów kolonialnych, jak: sierocińce, sądy czy więzienia. $\mathrm{Z}$ perspektywy czasu trudno jednak doszukiwać się bolesnych reinterpretacji przeszłości, która w zbiorowym wyobrażeniu jest jednak waloryzowana pozytywnie (Jeychandran 2016: 54-60).

Neelima Jeychandran - badaczka miejsc pamięci - nawiązuje do postkolonialnej przeszłości Fortu: „[...] Pomimo iż Fort Cochin przetrwał jako muzeum na otwartym terenie, które opowiada historię o kolonializmie, nie jest przestrzenią krytycznie kwestionującą kolonialny dyskurs. Etap kolonialny jest raczej zaprezentowany jako era wymiany wewnątrz kulturowej" (Jeychandran 2016: 60). W istocie, ten region Indii w przeszłości nie doświadczył rozlewu krwi. Specyficzny klimat rotacji kulturowej, swoistego styku kultur opartego na kupiectwie i wymianie towarów, umocnił poczucie identyfikacji z barwną przeszłością. Jeśli podgrzewał dążenia separatystyczne, to były one raczej widoczne w warstwie symbolicznej - chęci zachowania rodzimej kultury i tradycji. Być może dlatego drzewa są symbolem owego konsensu kulturowego, który wzniósł Keralę do rangi mitycznej krainy boga godzącego mieszające się tu kultury i religie.

Bez wątpienia, owe stare drzewa-matki sięgają do przeszłości i są jej symbolem. Tak jak korzeniami zasilają podziemne korytarze - przekazując soki innym drzewom, tak swoją obecnością „karmią” pamięć przodków. Tworzą narracje dotyczące tożsamości mieszkańców Fortu Kochi. Drzewa zatem reinterpretują kolonialną przeszłość regionu - w tym sensie są częścią historycznego dyskursu - większej historii opowiadającej o dziejach i przeszłości miasta. Co zasadnicze, odnoszą się też do małych opowieści mieszkańców Kochi - intymnych wspomnień, prywatnych wyznań, które zanurzone są w perspektywie ludzkich losów, historii sąsiedzkich, lokalnych wspomnień (Paleczny 2011: 57-59).

„Historia nieoficjalna wiąże się nierozerwalnie z narracją dotyczącą historii bliskiej «naszej», lokalnej, partykularnej, prywatnej i intymnej. Jest to wymiar mikro-historii, wielu równoległych, najczęściej komplementarnych, przenikających się narracji osobistych [...] Historia nieoficjalna z natury rzeczy jest historią żywą, aktualną, przeżywaną, a nie tylko archiwizowaną czy pamiętaną" (Paleczny 2011: 57).

W powyższym kontekście deszczowe drzewa-matki, olbrzymie baniany czy święte czerpnie gujańskie tworzą nową perspektywę postrzegania przeszłości. Są nie mniej wymowne niż muzea - można rzec, że tak samo święte i dostojne, jak stare kościoły czy synagogi. Drzewa również referują do teraźniejszości - uświetniając karnawał, czy nadając nazwy licznym domom gościnnym i hostelom (Raintree Lodge, Raintree Home Stay, Mother Tree Bead and Brekfast, Hotel Mother Tree, Banyan Tree Hotel, Ashoka Tourist Home). Ostatecznie są 
żywymi organizmami, które kwitną, gubią liście, wydają owoce, puszczają sok, łamią gałęzie - jednym słowem - komunikują się z człowiekiem zgodnie z rytmem monsunu, dnia i nocy czy pory roku. Mieszkańcy dostrzegają w nich opiekuńczą energię drzewa-matki, wierzą w niezwykłą więź, która powstaje między nimi i ludźmi. We wspomnieniu mieszkanki Fortu drzewo pełniło rolę troskliwego bóstwa i chroniło dom przed złymi mocami: „To była radość z dorastania w pobliżu drzewa, o którym moja nieżyjąca matka mówiła, że ma ponad 400 lat. W trakcie burzowych nocy bałam się, gdyż te wielkie gałęzie unoszące się nad naszym domem, trzęsły się gwałtownie pod wpływem wiatru. Dla mnie to była wielka dama chroniąca nas przed siłami zła. Zawsze uważałam, że drzewo miało swój charakter. Ilekroć przyjeżdżam do Indii, odwiedzam je, by odnowić niezwykłe więzi, które dzielimy" (Web-o7).

Działania zmierzające do zachowania dziedzictwa naturalnego w postaci admiracji starych drzew są bardzo ważne nie tylko z powodów społeczno-kulturowych. Kochi, który jest gęsto zaludniony, boryka się $\mathrm{z}$ typowymi problemami indyjskich miast - zanieczyszczeniem powietrza, skażeniem wody i uporczywym hałasem. Impulsem do zachowania dziedzictwa zieleni może być strategia miejsc pamięci, które tworzą drzewa. Jednak tam, gdzie zabraknie obszarów zbiorowych identyfikacji z przeszłością, pojawia się impuls do innych działań. Pozytywnym przykładem walki o zieloną przestrzeń jest postawa kobiety z sąsiadującego stanu Karnataka - Saalumarady Thimmakka (Web-09). Nazywana jest 105-letnią matką drzew, gdyż dawno temu podjęła inicjatywę ich sadzenia. Potrzeba wypływała z osobistego doświadczenia bezdzietności, które w tradycyjnych indyjskich społecznościach jest stygmatyzujące. Kobieta przekuła swe piętno na działanie, w efekcie którego wraz z mężem - Sri Bikkala Chikkayya - posadzili na drodze do swej wioski (Kudur) ponad 300 drzew - głównie banianów. Dbali o nie, jak o swoje dzieci, co zważywszy na suchy i pylisty krajobraz wymagało wiele pracy. Kopanie dołów, nawadnianie i sadzenie kolczastych krzewów, by zapobiec objadaniu roślin przez zwierzęta, stanowiło dodatkową pracę poza tą, którą wykonywali na farmie. Owo przedsięwzięcie dziś jest symbolem rytuału sadzenia drzew w Indiach. Kobieta doczekała się nie tylko międzynarodowych wyróżnień, lecz także naśladowców - przydzielono specjalne dotacje na wspieranie tego ekologicznego dzieła. Z dumą więc spogląda na swe dzieci, którymi nazywa posadzone drzewa. Kontynuuje zatem dzieło, pomimo śmierci męża, wraz z przybranym synem - Sri Umeshem. Chłopak, wiedziony chęcią pomocy i zafascynowany działalnością starszej pani, przybył do niej pewnego dnia, by wesprzeć ją w pracy. Dziś zajmuje się dowożeniem drzew na farmy i towarzyszeniem przybranej matce, by - jak twierdzi - nie była sama. Oboje więc kontynuują ideę sadzenia banianów dla przyszłych pokoleń, by zachować środowisko naturalne w możliwie najmniej zmienionej formie.

Dziedzictwo zieleni wskazuje na cienisty azyl, który łączy przeszłość, teraźniejszość i przyszłość. Dla mieszkańców Fortu Kochi jest też znakiem przywiązania do drzew, które mają nie tylko swe święte afiliacje, lecz takżę doniosłe historyczne znaczenie. Są zatem signum przeszłości, zielonym pomnikiem pamięci. Stają się też naturalnym łącznikiem z teraźniejszością, który jest widoczny szczególnie w czasie festiwalowych imprez czy też w ekologicznych przedsięwzięciach sadzenia drzew. Kolosy z Fortu Kochi dają przyczynek do dyskusji na temat przeszłości i historii regionu. Stanowią tło narracji osobistych, małych opowieści, które wymykają się swoim antropocentrycznym ramom. Owe nieantropocentryczne narracje ukazują relacje ze środowiskiem naturalnym - ściślej mówiąc - drzewem (Nimmo 2011: 79). Takie opowieści przestają być (zachodnim?) dyskursem człowieka wieńczącego koronę stworzenia. W Kochi koroną stworzenia jest drzewo deszczowe, pod którego baldachimem toczy się ludzkie życie, wspomina się przeszłość i rozgrywa się przyszłość. 


\section{Bibliografia}

Bennet T., 2004, Exhibitionary Complex, w: Grasping the World, red. C. Fargo, D. Preziosi, Farnham, Ashgate Publishing, 413-441.

Jeychandran N., 2016, Colonial Spaces, Postcolonial Narratives. The Exhibitionary Landscape of Fort Cochin in India, w: The Postcolonial Museum: The Arts of Memory and the Pressures of History, red. I. Chambers, A. De Angelis, C. Ianniciello, A. Oraboba, London - New York, Routledge.

Kieniewicz J., 1980, Historia Indii, Wrocław-Warszawa, Zakład Narodowy im. Ossolińskich.

Nimmo R., 2011, The Making of the Human: Anthropocentrism in Modern Social Thought, w: Anthropocentrism: Humans, Animals, Environments, red. R. Boddice, 79 Leiden-Boston, BRILL.

Paleczny T., 2011, Narracja historyczna w perspektywie kulturoznawczej - kilka ogólnych refleksji, w: Przesztość we wspótczesnej narracji kulturowej. Studia i szkice kulturoznawcze, red. P. Biliński, t. 1, Kraków, Wydawnictwo Uniwersytetu Jagiellońskiego, 57-59.

Renik K., 1994, Kathakali, sztuka indyjskiego teatru, Warszawa, Dialog.

Szpociński A., 2008, Miejsca pamięci (lieux de mémoire), Teksty Drugie, 4, 11-20.
Web-o1, Couroupita guianensis, Cannonball Tree, www.eol.org/pages/1054983/overview, dostęp: 15.03.2017.

Web-o2, Bania, People Groups of India, www.peoplegroupsindia.com/profiles/bania, dostęp: 25.03.2017.

Web-o3, Significance of the Banyan, http://timesofindia.indiatimes.com/city/nagpur/Significance-of-the Banyan/articleshow/8856719.cms, dostęp: 25.03.2017.

Web-04, Trees of Fort Cochi, KochiCoo. Fall in love with Kochi, https://kochicoo.wordpress. com/2016/o3/26/trees-of-fort-kochi, dostęp: 25.03.2017.

Web-05 Albizia samam, www.eol.org/data_objects/32459088, dostęp: 26.03.2017.

Web-o6 At the root of the problem, http://news.ubc.

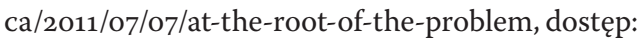
26.03.2017.

Web-07 Witness of generations, www.thehindu. com/todays-paper/tp-features/tp-metroplus/ Witness-to-generations/article15707810.ece, dostęp: 25.03.2017.

Web-o8 Cochin Carnival 2011, http://kochimirror. blogspot.com/2011/12/cochin-carnival-starts-from-18-th.html, dostęp: 27.03.2017.

Web-o9 India's 105-year-old mother of trees, http:// edition.cnn.com/2016/11/04/asia/saalumarada-thimmakka-trees-india, dostęp: 29.03.2017.

\title{
In the shadow of the rain tree: Anthropological notes from Fort Kochi
}

\begin{abstract}
The greenery heritage of Kerala's Fort Kochi is represented by its enormous trees, which, according to legend, remember India's colonial past. They are living monuments of the memory, with all of their cultural contexts. The locals of Fort Kochi identify with these giant trees, which are also seen as structures of long duration. Rain trees and big banyans are equated to a mother-tree which feeds the underground roots with life-giving energy. There is a cultural analogy between the old growth of trees roots and the cultural landscape of Fort Kochi, which recalls a web-like connection of historical and cultural identity with emotional biographies that endure in the shadow of the trees. Inhabitants of Fort Kochi worship and decorate the old tree giants in an annual festival. This is a symbol of symbiotic life between a multi-cultural society and nature.
\end{abstract}

\section{Keywords}

India, Fort Kochi, greenery heritage, rain tree, places of memory 